\begin{tabular}{|c|c|c|c|c|c|}
\hline \multicolumn{6}{|c|}{ DISTRIBUTION SHEET } \\
\hline \multirow{2}{*}{$\begin{array}{l}\text { To } \\
\text { Distribution }\end{array}$} & \multirow{2}{*}{\multicolumn{3}{|c|}{$\begin{array}{l}\text { From } \\
\text { Characterization Support }\end{array}$}} & \multicolumn{2}{|c|}{ Page 1 of 1} \\
\hline & & & & \multicolumn{2}{|c|}{ Date 11-22-94 } \\
\hline \multicolumn{4}{|l|}{ Project Title/Work Order } & \multicolumn{2}{|c|}{ EDT No. 609594} \\
\hline \multicolumn{6}{|c|}{ Tank 241-AW-101 Tank Characterization Plan (WHC-SD-WM-TP-229) } \\
\hline Name & MSIN & $\begin{array}{l}\text { Text } \\
\text { With All } \\
\text { Attach. }\end{array}$ & Text Only & $\begin{array}{l}\text { Attach./ } \\
\text { Appendix } \\
\text { Only }\end{array}$ & $\begin{array}{l}\text { EDT/ECN } \\
\text { Only }\end{array}$ \\
\hline
\end{tabular}

ONSITE

MACTEC
J. P. Haney
D. R. Lincoln
J. A. Sheriff
$57-73$
$57-73$
B1-42
$x$
$X$
$X$

Pacific Northwest Laboratories

S. F. Bobrowski

K7-28

S. G. McKinley

P7-22

$x$

Westinghouse Hanford Company

H. Babad

K. E. Bell

J. L. Deichman

S. J. Eberlein

V. W. Hall

D. W. Hamilton

G. D. Johnson

K. K. Keller

J. G. Kristofzski

J. B. Little

N. G. McDuffie

G. J. Miskho

P. M. Morant

A. D. 01guin

A. D. Rice

P. Sathyanarayana (2)

R. D. Schreiber (5)

C. L. Thomas

T. C. Trible

Central Files

O.S.T.I. (2)

$\begin{array}{ll}\text { S7-30 } & X \\ \text { T6-06 } & X \\ H 4-19 & X \\ \text { S7-31 } & X \\ H 4-19 & X \\ \text { S7-03 } & X \\ \text { S7-15 } & X \\ \text { S1-57 } & X \\ \text { T6-06 } & X \\ \text { S7-04 } & X \\ \text { S7-15 } & X \\ \text { S7-12 } & X \\ \text { H4-19 } & X \\ \text { S7-04 } & X \\ \text { T6-06 } & X \\ \text { R2-12 } & X \\ \text { R2-12 } & X \\ \text { H4-19 } & X \\ \text { S1-57 } & X \\ \text { L8-04 } & X \\ \text { L8-07 } & X\end{array}$




\section{DISCLAIMER}

Portions of this document may be illegible in electronic image products. Images are produced from the best available original document. 


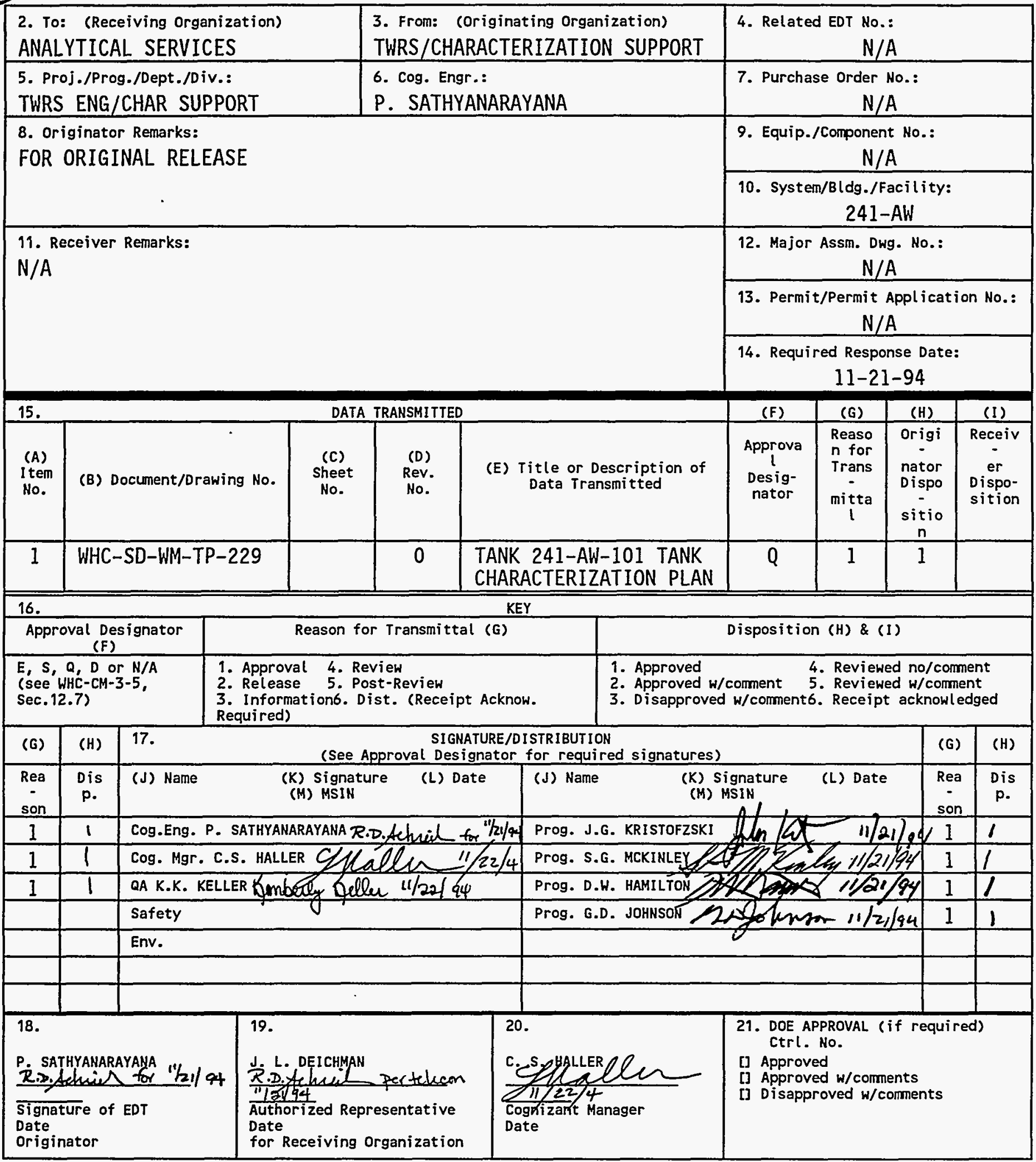




\section{RELEASE AUTHORIZATION}

Document Number: $\quad$ HHC-SD-WM-TP-229, REV.0

Document Title: TANK 241-AW-101 TANK CHARACTERIZATION PLAN

Release Date: $\quad$ November 22, 1994

\section{This document was reviewed following the procedures described in WHC-CM-3-4 and is:}

\section{APPROVED FOR PUBLIC RELEASE}

WHC Information Release Administration Specialist:

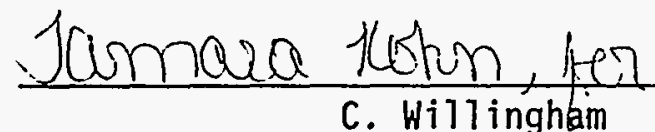

November 22, 1994

TRADEMARK DISCLAIMER. Reference herein to any specific commercial product, process, or service by trade name, trademark, manufacturer, or otherwise, does not necessarily constitute or imply its endorsement, recomendation, or favoring by the United States Government or any agency thereof or its contractors or subcontractors.

This report has been reproduced from the best available copy. Available in paper copy and microfiche. Printed in the United States of America. Available to the U.S. Department of Energy and its contractors from:

U.S. Department of Energy

office of Scientific and Technical Information (OSTI)

P.0. Box 62

Oak Ridge, TN 37831

Telephone: (615) 576-8401

Available to the public from:

U.S. Department of Commerce

National Technical Information Service (NTIS)

5285 Port Royal Road

Springfield, VA 22161

Telephone: (703) 487-4650 


\begin{tabular}{|c|c|}
\hline $\begin{array}{l}\text { 2. Title } \\
\text { TANK 241-AW-101 TANK CHARACTERIZATION PLAN }\end{array}$ & $\begin{array}{l}\text { 3. Number } \\
\text { WHC-SD-WM-TP-229 }\end{array}$ \\
\hline $\begin{array}{l}\text { 5. Key words } \\
\text { CHARACTERIZATION, FLAMMABLE GAS, DOUBLE-SHELL } \\
\text { TANK, SAMPLING, ANALYSIS, TANK CHARACTERIZATION } \\
\text { PLAN, CRUST BURN ISSUE AP } \\
\text { (U) } 11 / 2299 \text { PU }\end{array}$ & $\begin{array}{l}\text { 6. Author } \\
\text { Name: P. SATHYANARAYANA } \\
\text { R.D.Achuil for } 11 / 21 / 94 \\
\text { Signature } \\
\text { Organization/Charge code } 71520 / N 4168\end{array}$ \\
\hline
\end{tabular}

\section{Abstract}

This document is a plan which serves as the contractual agreement between the Characterization Program, Sampling Operations, WHC 222-S Laboratory, and PNL 325 Analytical Chemistry Laboratory. The scope of this plan is to provide guidance for the sampling and analysis of samples for tank 241-AW-101.

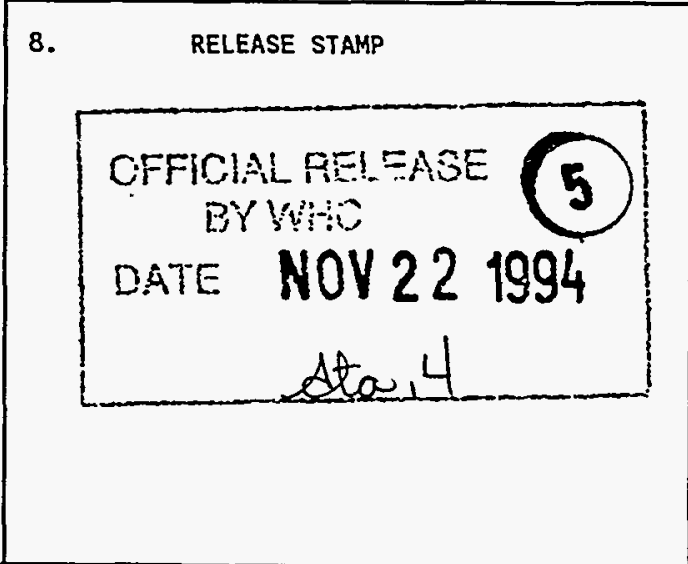


WHC-SD-WM-TP-229

Revision 0

\title{
Tank 241-AW-101 Tank Characterization Plan
}

\author{
Prepared for the U.S. Department of Energy \\ Office of Environmental Restoration \\ and Waste Management
}

\section{DISCLAIMER}

This report was prepared as an account of work sponsored by an agency of the United States Government. Neither the United States Government nor any agency thereof, nor any of their employees, makes any warranty, express or implied, or assumes any legal liability or responsibility for the accuracy, completeness, or usefulness of any information, apparatus, product, or process disclosed, or represents that its use would not infringe privately owned rights. Reference herein to any specific commercial product, process, or service by trade name, trademark, manufacturer, or otherwise does not necessarily constitute or imply its endorsement, recommendation, or favoring by the United States Government or any agency thereof. The views and opinions of authors expressed herein do not necessarily state or reflect those of the United States Government or any agency thereof.

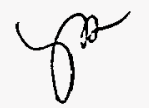


WHC-SD-WH-TP-229, REV. 0

\section{CONTENTS}

TANK AND WASTE INFORMATION

AGE AND PROCESS HISTORY OF TANK AW-101

EXPECTED TANK CONTENTS

REFERENCES ............................. 4 APPENDICES

A SAMPLING AND ANALYSIS PLAN FOR AUGER SAMPLING IN FISCAL YEAR 1995 . . . . . A-1

\section{LIST OF TABLES}

1 Fill History of Tank AW-101 . . . . . . . . . . . . . . . 2

2 Tank AW-101 Waste Composition ................... 3

\section{LIST OF ABBREVIATIONS}

AW-101 Tank 241-AW-101

CCPLX complexant concentrate waste

DSS double-shell slurry

RESID residual evaporator 1 iquor

TL terminal liquor 
WHC-SD-WH-TP-229, REV. 0

TANK AND WASTE INFORMATION

This section gives a summary of the available information for tank AW-101. Included in the discussion are the process history and recent sampling events for the tank, as well as general information about the tank such as its age and the risers to be used for sampling.

\section{AGE AND PROCESS HISTORY OF TANK AW-101}

Tank AW-101 is a double-she 17 tank that was constructed from 1978 to 1980 and began receiving waste during the first quarter of 1981. It has a tank capacity of $1,160,000$ gallons $\left(4390 \mathrm{~m}^{3}\right)$. Table 1 summarizes the fill history from the time AW-101 entered service until the present time.

\section{EXPECTED TANK CONTENTS}

Double Shell Slurry Feed (DSSF) is noncomplexed waste that has been concentrated in the evaporators. The solution is formed just before reaching the sodium aluminate saturation boundary (of $6.5 \mathrm{molar}$ hydroxide). Further evaporation yields a slurry that is not suitable for storage in SSTs. This form is not as concentrated as Double-She11 sTurry (DSS).

The most recent sampling event for tank AW-101 was performed on June 28, 1990 by Westinghouse Hanford Operations. Twelve 100-ml samples from three different risers. $10 \mathrm{~A}, 22 \mathrm{~A}$ and $16 \mathrm{C}$ were taken in preparation for disposal. The analytical results were used to evaluate the homogeneity of the tank waste. Statistical analysis of the resulting data indicated that the tank contents are homogeneous. Therefore a composite sample was formed using equal volumes of the individual samples. Using the analytical results of individual and composite samples, an overall character of the waste is provided in Table 2. Based on the major analytes given for DSSF waste, and the sampling information from 1990, it is expected that the AW-101 waste will contain high amounts of $\mathrm{Na}^{+}, \mathrm{OH}^{-}, \mathrm{NO}_{3}^{-}, \mathrm{NO}_{2}^{-}, \mathrm{K}^{+}$and $\mathrm{Al}^{+}$.

The surface elevation of the waste of tank AW-101 has shown cyclic perturbations with an amplitude of around 2". The manual tape readings indicate that the mean waste elevation is increasing about 2" per year.

On October 4, 1994, AW-101 had a gas release event. The peak hydrogen concentration was about $0.88 \%$, which is close to $25 \%$ of the Lower Flammability Limit (LFL). Actions for mitigation are required when the gas fuel content reaches $25 \%$ of the LFL. The total surface drop was 0.75 inches with 0.55 inches occurring on the first day. Little change in tank pressure was observed (Wilkins 1994).

Tank AW-101 has been involved as the feed or the slurry tank for nine campaigns of evaporator 242A. During campaign 85-3, the submersible pump in tank AW-101 failed. During pump removal, it was reported that the pump would not fit through the 12 inch riser. The support cable was cut, and the pump was allowed to fall back into the tank. To date the pump is still lying on the bottom of the tank 101-AW. An unreviewed safety question screening was performed on the submersibie pump. The screening found no USQ issues involved (White 1993). 
WHC-SD-HM-TP-229, REV. 0

Table 1: Fill History of Tank AW-101 ${ }^{\mathrm{a}}$.

\begin{tabular}{|c|c|c|}
\hline Date & Waste Type and Description & $\begin{array}{l}\text { Total } \\
\text { Vol ume } \\
\text { (kgal) }\end{array}$ \\
\hline $1978-1981$ & Under Construction & 0 \\
\hline $2 / 1981-11 / 1981$ & DiTute Non-Complexed Waste & 1106 \\
\hline $11 / 1981$ & Transfer to AW-102 & 0 \\
\hline $12 / 1981-3 / 1982$ & $\begin{array}{c}\text { Cross-site transfer from SY-102 } \\
\text { of waste }\end{array}$ & 988 \\
\hline $11 / 1982$ & $\begin{array}{c}\text { Transfer to Evaporator feed tank } \\
\text { Al-102 }\end{array}$ & 33 \\
\hline $4 / 1983-5 / 1984$ & Transfer from $\mathrm{AW}-105$ and $\mathrm{AZ}-102$ & 1129 \\
\hline $6 / 1984-3 / 1986$ & $\begin{array}{l}\text { Various transfers from PUREX, } \\
\text { and Transfers to evaporator }\end{array}$ & 810 \\
\hline $5 / 1986$ & $\begin{array}{c}\text { Transfer to AW-102 evaporator } \\
\text { fill tank }\end{array}$ & 54 \\
\hline $6 / 1986-4 / 1994$ & Evaporator slurry & $1124^{\mathrm{b}}$ \\
\hline
\end{tabular}

a (Brager 1993).

b This includes $1040 \mathrm{kgal}$ of drainable, pumpable liquid and $84 \mathrm{kgal}$ of sludge. 
WHC-SD-WM-TP-229, REV. 0

Table 2: Tank AW-101 Waste Composition a .

\begin{tabular}{|c|c|}
\hline Component & Mean result \\
\hline Aluminum & $1.033 \mathrm{M}^{\circ}$ \\
\hline Calcium & $8.25 E-04 M$ \\
\hline Chromium & $3.088 \mathrm{E}-03 \mathrm{H}$ \\
\hline Magnesium & $2.155 \mathrm{E}-03 \mathrm{M}$ \\
\hline Manganese & $4.756 E-04 M$ \\
\hline Molybdenum & $5.995 \mathrm{E}-04 \mathrm{M}$ \\
\hline Potassium & $1.068 \mathrm{M}$ \\
\hline Sodium & $1.001 E+01 \mathrm{H}$ \\
\hline Uranium & $9.39 E-04 H$ \\
\hline Ammonia & $1.45 \mathrm{E}-02 \mathrm{H}$ \\
\hline Carbonate & $2.052 E-01 M$ \\
\hline Chloride & $1.46 E-01 M$ \\
\hline Cyanide & $1.030 E-03 M$ \\
\hline Hydroxide & $5.072 \mathrm{M}$ \\
\hline Nitrite -s & $2.163 \mathrm{M}$ \\
\hline Nitrite -D & $2.212 \mathrm{M}$ \\
\hline Nitrate & $3.456 \mathrm{M}$ \\
\hline Phosphate & $2.218 \mathrm{E}-02 \mu$ \\
\hline Sulphate & $1.074 \mathrm{E}-02 \mathrm{M}$ \\
\hline Tritium ${ }^{c}$ & $7.07 \mu \mathrm{Ci} / \mathrm{L}$ \\
\hline Carbon-14 & $3.7 \mathrm{E}-01 \mu \mathrm{Ci} / \mathrm{L}$ \\
\hline Selenium-79 & $4.8 \mathrm{E}-01 \mu \mathrm{Ci} / \mathrm{L}$ \\
\hline$s r-89 / 90$ & $1.085 \mathrm{E}+03 \mu \mathrm{Ci} / \mathrm{L}$ \\
\hline TC-99 & $1.52 \mathrm{E}+02 \mu \mathrm{Ci} / \mathrm{L}$ \\
\hline Iodine-129 & $3.03 \mathrm{E}-01 \mu \mathrm{Ci} / \mathrm{L}$ \\
\hline Cesium- 134 & $1.526 \mathrm{E}+03 \mu \mathrm{Ci} / \mathrm{L}$ \\
\hline Cesium- 137 & $5.197 \mathrm{E}+05 \mu \mathrm{Ci} / \mathrm{L}$ \\
\hline Pu-239/240 & $1.145 \mu \mathrm{Ci} / \mathrm{L}$ \\
\hline Am-241 & $1.204 \mu \mathrm{Ci} / \mathrm{L}$ \\
\hline $\mathrm{Cm}-243 / 244$ & 5.33E-02 $\mu \mathrm{Ci} / \mathrm{L}$ \\
\hline TOC & $2.460 \mathrm{~g} / \mathrm{L}$ \\
\hline Water & $4.36 E+01 w t \%$ \\
\hline Density & $1.56 \mathrm{~g} / \mathrm{cm}^{3}$ \\
\hline
\end{tabular}

a (Welsh 1991)

$b$ units of molarity.

c Standards were outside laboratory quality control limits.

d Density measured by AC personnel

Nitrite-s: Nitrite measured using a spec method

Nitrite-D: Nitrite measured using the dionex method 
WHC-SD-WM-TP-229, REV. 0

\section{REFERENCES}

Anderson, J. D., 1992, A History of the 200 Area Tank Farms, WHC-MR-0132, Westinghouse Hanford Company, Richland, Washington.

Brager, H. R., 1993, Summary of Information on Flammable Gas Watch List Tanks, WHC-EP-0711, Westinghouse Hanford Company, Richland.

Hanton, B. M., 1993, Tank Farm Surveillance and Waste Status Summary Report for April 1994, WHC-EP-0182-73, Westinghouse Hanford Company, Richland, Washington.

We1sh, T. L., 1991, Tank 241-AW-101 Characterization Resu7ts, WHC-SD-WM-TRP-055, Rev. 0, Westinghouse Hanford Company, Richland.

White, K., 1993, Presence of submersible pump in 241-AW-101, DSI, Westinghouse Hanford Company, Richland.

Wilkins, N. E., Internal memo to G. D. Johnson, "Gas Release Event in Tank 241-AW-101", 7E310-94-054, dated October 19, 1994. 
WHC-SD-WM-TP-229, REV. 0

APPENDIX A

SAMPLING AND ANALYSIS PLAN FOR AUGER SAMPLING

IN FISCAL YEAR 1995

$A-1$ 
WHC-SD-WM-TP-229, REV. 0

This page intentionally left blank.

A-2 
WHC-SD-WM-TP-229, REV. 0

CONTENTS

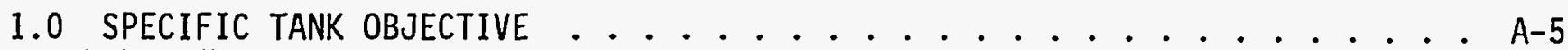

1.1 RELEVANT SAFETY ISSUES ....................... . . . . .

1.1.1 AW-101 Characterization Objectives . . . . . . . . . A-5

1.1.2 Flammable Gas Crust Burn Data

Quatity Objective .................. A-6

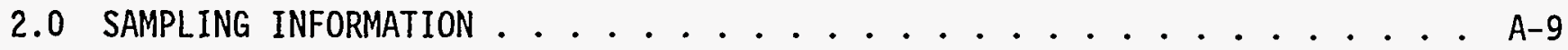

3.0 SAMPLE REMOVAL AND BREAKDOWN INSTRUCTIONS ............ A-9

3.1 HOT CELL BREAKDOWN INSTRUCTIONS ................ . A-9

3.2 INSUFFICIENT AUGER SAMPLE ...................... A-10

4.0 SPECIFIC ANALYTE, QUALITY CONTROL, AND DATA CRITERIA . . . . . . . . A-12

4.1 SPECIFIC METHODS AND ANALYSES . . . . . . . . . . . . A A-12

4.2 QUALITY ASSURANCE/QUALITY CONTROL $\ldots \ldots \ldots \ldots$ A-12

4.2.1 Laboratory 0perations . . . . . . . . . . . . . A-12

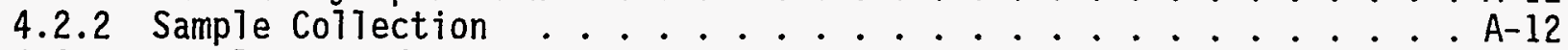

4.2 .3 Sample Custody . . . . . . . . . . . . . A-13

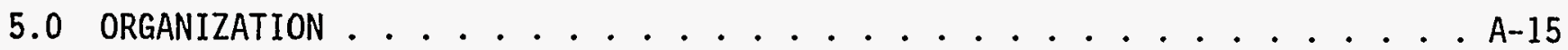

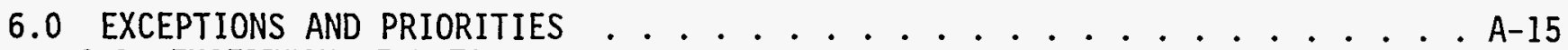

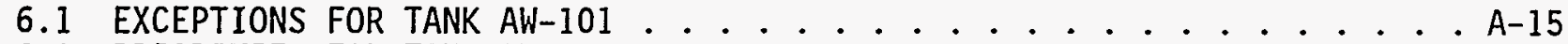

6.2 PRIORITIES FOR TANK AW-101 .......................... . . . .

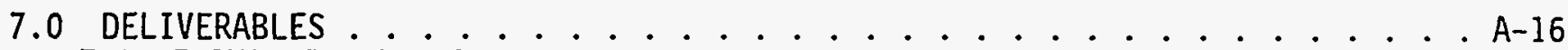

7.1 FORMAT I REPORTING . . . . . . . . . . . . . A-16

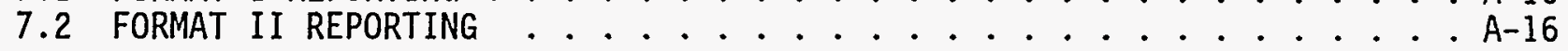

8.0 CHANGE CONTROL . . . . . . . . . . . . . . A A-17

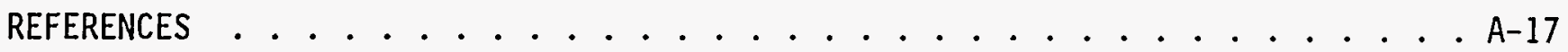


WHC-SD-WM-TP-229, REV. 0

LIST OF TABLES

Table A-1

AW-101 Auger Sample Chemical, Physical, and Radiological

Analytical Requirements ............. A-14

Table A-2

Tank AW-101 Project Key Personnel List . . . . . . . . . A-15

\title{
LIST OF FIGURES
}

Figure A-1 Flow Logic for Addition of Water and Crust Burn Safety Issue . . A-8

Figure A-2 Test Plan Flowchart for Tank AW-101 . . . . . . . . . A-11

\section{LIST OF ABBREVIATIONS}

\author{
ACL Analytical Chemistry Laboratory \\ AMS analytical measurement system \\ AW-101 Tank 241-AW-101 \\ DNFSB Defense Nuclear Facility Safety Board \\ DOE Department of Energy \\ DQO data quality objective \\ DSC differential scanning calorimetry \\ DST double-shell tank \\ ECN engineering change notice \\ GEA gamma energy analysis \\ QA quaTity assurance \\ RSST reactive system screening tool \\ SST single-shel1 \\ SY-101 tank 241-SY-101 \\ TGA thermogravimetric analysis \\ TIC total inorganic carbon \\ TOC total organic carbon \\ TWRS Tank Waste Remediation System \\ USQ unreviewed safety question \\ WHC Westinghouse Hanford Company
}




\subsection{SPECIFIC TANK OBJECTIVES}

An early safety issue, originally raised for Flammable Gas Watch List tank 241-SY-101 (SY-101), concerned the potential of a chemical reaction in the crust layer of the waste occurring as a result of a postulated gas burn or intrusive activities such as core sampling. The issue was successfully resolved for tank SY-101, and characterization has proceeded for other Flammable Gas Watch List tanks to provide inputs for decisions on water addition and resolution of this crust burn safety issue. Tank 241-AW-101 is one of the 25 tanks on the Flammable Gas Watch List. In general, there are safety issues related to public and worker health that have been associated with the Hanford Site underground storage tanks: ferrocyanide, flammable gas, criticality, high heat, organic, and vapor (Babad 1992).

\subsection{RELEVANT SAFETY ISSUES}

Flammable gas generation, retention, and release is a top priority waste tank safety issue at the Hanford Site. In March 1990, the potential for a large quantity of hydrogen and nitrous oxide to exist as an explosive mixture within the waste was declared an Unreviewed Safety Question (USQ). To resolve the Flammable Gas safety issue, characterization of the tanks, including intrusive tank sampling, must be performed. Prior to sampling, however, the potential for the following scenarios must be evaluated:

- The potential for ignition of flammable gases such as hydrogen-air and/or hydrogen-nitrous oxide

- The potential for secondary ignition of organic-nitrate/nitrate mixtures in crust layer initiated by the burning of flammable gases or by a mechanical in-tank energy source.

The first concern above will be addressed by a separate DQO. The second concern has been termed a "crust burn" issue. Crust heating by a burning gas or by mechanical energy, such as from friction during core sampling, could initiate an exothermic reaction between organic carbon and the nitrate or nitrite compounds. If the crust material reached a sufficiently high temperature, volatile components could be released as aerosols. Radionuclides carried with the aerosols would be a radioactive source term to the public and the environment (Johnson 1994).

Since tank AW-101 is to be core sampled in fiscal year 1995, the Flammable Gas Tank Safety Program has identified the basic question to be answered regarding the crust burn issue: "Is there a possibility of having a crust burn as a result of core sampling in the tank?" The following two related questions must then be resolved: (1) "Does water need to be added to the area where push mode core sampling is to take place?", and (2) "If the potential for a crust burn exists, then what additional actions are needed to address the safety issue?"

\subsubsection{AH-101 Characterization Objectives}

The characterization effort applicable to this Tank Characterization Plan is focused on the resolution of the crust burn flammable gas safety issue of tank AW-101. The Defense Nuclear Facilities Safety Board has directed the DOE (Conway 1993), and subsequently Westinghouse Hanford Company, to concentrate the near-term 
sampling and analysis activities on identification and resolution of safety issues.

The characterization of tank AW-101 is necessary to resolve the crust burn safety issue and the flammable gas safety issue in general. To evaluate the potential for a crust burn of the waste material, calorimetry tests will be performed on the waste. Differential Scanning Calorimetry (DSC) will be used to determine whether an exothermic reaction exists. If the DSC shows that a total energy (summation of endothermic and exothermic energy) greater than $0 \mathrm{cal} / \mathrm{g}$ exists, but the net exothermic energy (summation of exothermic energy alone) is less than $140 \mathrm{cal} / \mathrm{g}$ (on a dry weight basis) in tank AW-101, personnel at the 222-S Laboratory wi1l consu1t with the Flammable Gas Safety Program to determine if an adiabatic calorimetry method, Reactive System Screening Tool (RSST), will be used to characterize the exothermic behavior. If the laboratory can demonstrate from the analyses (see Section 4.1) that the net exothermic energy is statistically significantly less than $140 \mathrm{cal} / \mathrm{g}$, no RSST will be performed. However, if the DSC result indicates a net exothermic energy statistically close to $140 \mathrm{cal} / \mathrm{g}$, adiabatic calorimetry may be used to verify the DSC energetics result and to understand the reactions involved. More detailed information on the calorimetry and other analyses to be performed on the waste may be found in (Johnson 1994).

Resolution of the AW-101 crust burn issue is dependent upon the result of the following decision rule:

"Does the maximum value of DSC tests show a net positive exothermic energy and does the maximum [exothermic] energy value from [DSC or] RSST tests exceed 140 cal/g?"

Figure 1 shows the logic flow for this decision rule. If the answer to this question is yes, then water addition is required prior to core sampling. The amount of water addition will need to be determined based on the results of the DSC/TGA and RSST analyses. As we11, a detailed burn and consequence analys is is needed in order to define the safety basis and to establish proper work controls (Johnson 1994). If the answer is "no", it will be necessary to see if a dry crust ring is present in the tank via an in-tank television camera, and if it is not, then it will not be necessary to add water to the tank during core sampling. Also, the crust burn issue will be closed. If there is a dry crust ring, radiochemical data will need to be obtained and the burn and consequence analysis will need to be done. If the answer to the second part of the decision rule is "no", the crust burn issue can be closed.

Entrance into a tank with a USQ is hindered by requirements for preparation of additional safety and environmental documentation and approval by DOE management. For this sampling event, the following documentation has been submitted to and approved by DOE: "Notification of Intent to Conduct Activities at Double-She]1 Tanks" (Johnson 1994b).

\subsubsection{Flammable Gas Crust Burn Data Quality Objective}

The report "Data Requirements Developed through the Data Quality Objectives Process for the Crust Burn Issue Associated with Flammable Gas Tanks" (Johnson 1994) describes the sampling and analytical requirements for tank AW-101 with respect to this specific safety issue. Tank Safety Screening Data Quality objective (Redus and Babad 1994) describes the sampling and analytical requirements for screening waste tanks for unidentified safety issues. This safety screening module 
WHC-SD-WM-TP-229, REV. 0

will be employed when tank $A W-101$ is core sampled later this fiscal year. Since the waste is to be auger sampled during this sampling event, the needs expressed in the core sampling-based DQO are not applicable and will be considered when the tank is core sampled. Directions for that sampling and analysis activity will be issued as an Engineering Change Notice (ECN) to this Supporting Document. 
WHC-SD-WM-TP-229, REV. 0

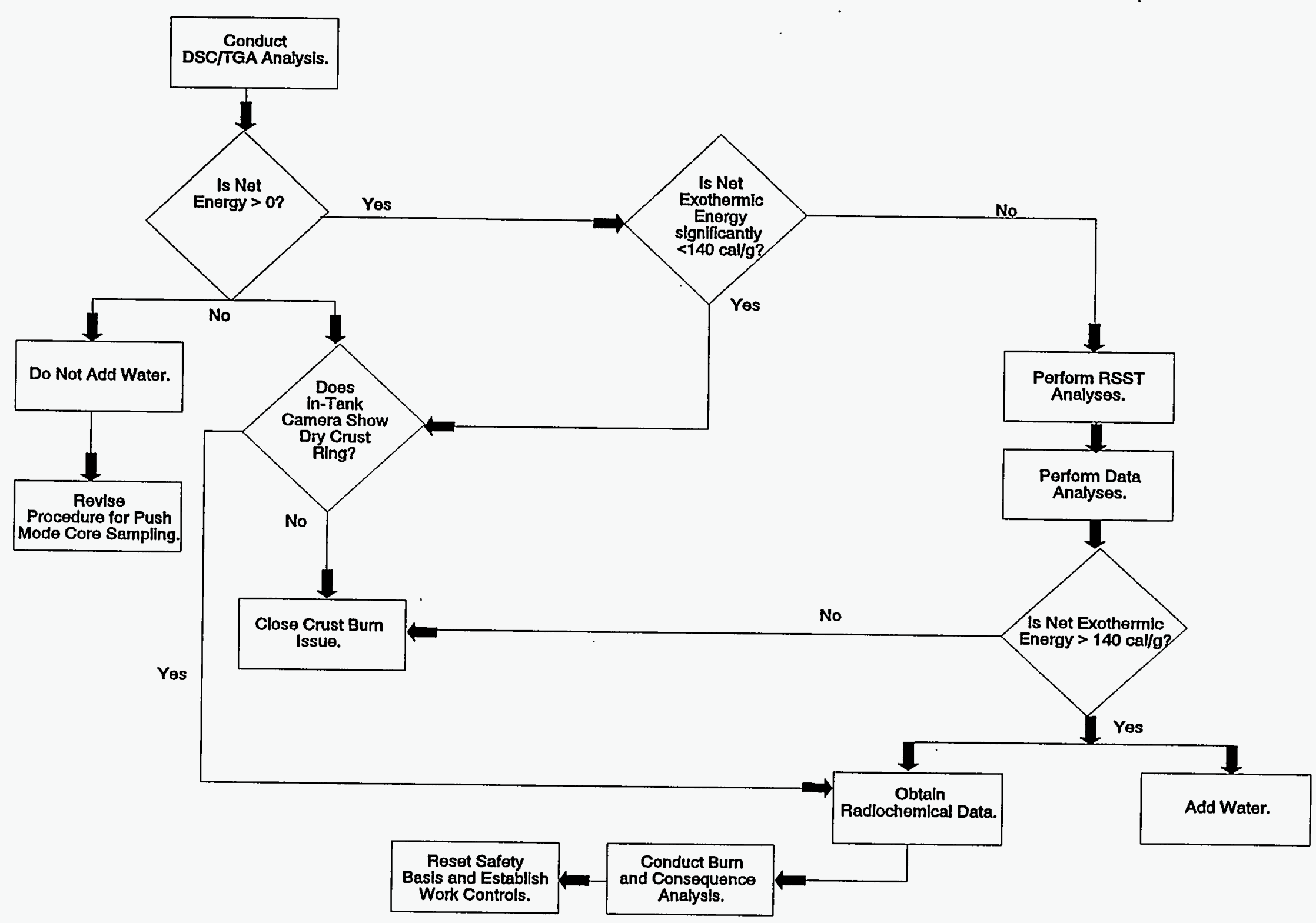

Figure A-1: Flow Logic for Addition of Water and Crust Burn Safety Issue 
WHC-SD-WM-TP-229, REV. 0

\subsection{SAMPLING INFORMATION}

Tank AW-101 is scheduled to be sampled by the auger method. According to the specifications set by (Johnson 1994), three auger samples shall be taken from widely spaced risers. Risers $12 A, 13 A$, and $24 A$ will be used for the sampling event. Risers $12 \mathrm{~A}$ and $24 \mathrm{~A}$ are both 12 inch diameter risers, while riser $13 \mathrm{~A}$ has a diameter of 4 inches. For detailed information regarding the AW-101 auger sampling activities, refer to work package ES-94-906. This document will contain all the applicable operating procedures and the chain of custody records for this sampling event.

Current records indicate that there are a total of $1124 \mathrm{kgals}$ of waste in tank AW-101, including $1040 \mathrm{kgals}$ of drainable, pumpable liquids, and $84 \mathrm{kgals}$ of sludge. This volume of waste corresponds to 409.4 inches of waste. Since the auger method will be used, 8 inches of sample (approximately $300 \mathrm{~g}$ of waste if complete recovery is obtained) are expected to be recovered from each auger sample. No drainable liquids are expected to be obtained, as the auger is not designed to collect liquids. However, some liquids may be trapped in the waste. Therefore, the handling of 7 iquid samples has been included in section 3.0, "Sample Removal and Breakdown Instructions".

With respect to sampling quality control, Waste Tank Sampling Engineering will not be taking a field/trip blank for this sampling event. Field/trip blanks are samplers filled with deionized water which are then shipped to the performing laboratory with the sample to measure contamination during shipping. Since the data obtained from these analyses are not being used to make decisions regarding treatment or disposal of waste, a field/trip blank is not necessary and will therefore not be taken during. this sampling event.

\subsection{SAMPLE REMOVAL AND BREAKDOWN INSTRUCTIONS}

\subsection{HOT CELL BREAKDOWN INSTRUCTIONS}

A flowchart showing the general sampling and analysis scheme for tank AW-101 is presented as Figure 2. A11 three auger samples are to be analyzed in accordance with Figure 2. This analysis scheme assumes adequate sample, including a dry crust layer, exists to perform all the analyses. Before sample removal and breakdown begins, N. G. McDuffie or another delegate of the Flammable Gas Safety Program shall be contacted so that they may be present to observe the breakdown procedures and guide the laboratory personnel in the case of an unusual sample. Any deviations to Figure 2, decisions, or observations during the sample removal sha71 be documented. These decisions and observations shall also be reported in the data report. The reporting formats for analyses are contained in Table A-1. A7though there are no special holding time requirements, samples for moisture analysis should be taken as quickly as possible to avoid evaporative loss.

It should be noted that in accordance with the Sampling and Analysis Report for Packaging (SARP), the casks in which the tank AW-101 samples are shipped to the laboratory must be vented every 15 days from the time of cask sealing in order to allow any gases to escape. The time of each cask sealing will be noted on the chain-of-custody form which accompanies the sample to the lab. 
WHC-SD-WM-TP-229, REV. 0

No Tiquids are expected from this tank AW-101 sampling event. However, if liquids are obtained, they shall be analyzed for the same suite of analyses as the solid samples.

Two points should be made concerning the AW-101 auger sample removal. First, the auger cask and liner, which will be received in a vertical position, should not be tipped past the horizontal position. If the liner is tipped past horizontal while the auger is being removed, any information on waste stratification will be 1ost. Secondly, the AW-101 auger samples are not to be homogenized. The primary purpose of this sampling event is the determination of the maximum net exothermic energy in crust samples from tank AW-101. If the sample is homogenized, any dry crust 1ayer, where the net exothermic energy will be greatest, will be diluted by the more moist sludge waste expected towards the bottom of the sample, causing an inaccurate evaluation of the safety boundary.

\subsection{INSUFFICIENT AUGER SAMPLE}

If the amount of sample from tank AW-101 is found to be insufficient to perform the analyses in Table A-1, Characterization Support and Analytical Services shall be notified (for points of contact, see Section 5.0, Table A-2). However, analysis of the AW-101 samples shall not be delayed. A prioritized suite of analyses has been included in section 6.2 to expedite the analys is effort. Any analyses prescribed by this document, but not performed, shall be identified in the appropriate data report. If there is insufficient sample material to perform duplicates on all of the analyses, duplicate analyses should be done in the following manner: (1) DSC/TGA in duplicate; (2) RSST (not in duplicate due to constraints of sample size); (3) radionuclides in duplicate; (4) TOC in duplicate. In other words, DSC/TGA shall be done in duplicate before RSST, radionuclides, or TOC analyses are performed. Also in this situation, Characterization Support and Hanford Analytical Services personnel shall be contacted. 
WHC-SD-WM-TP-229, REV. 0

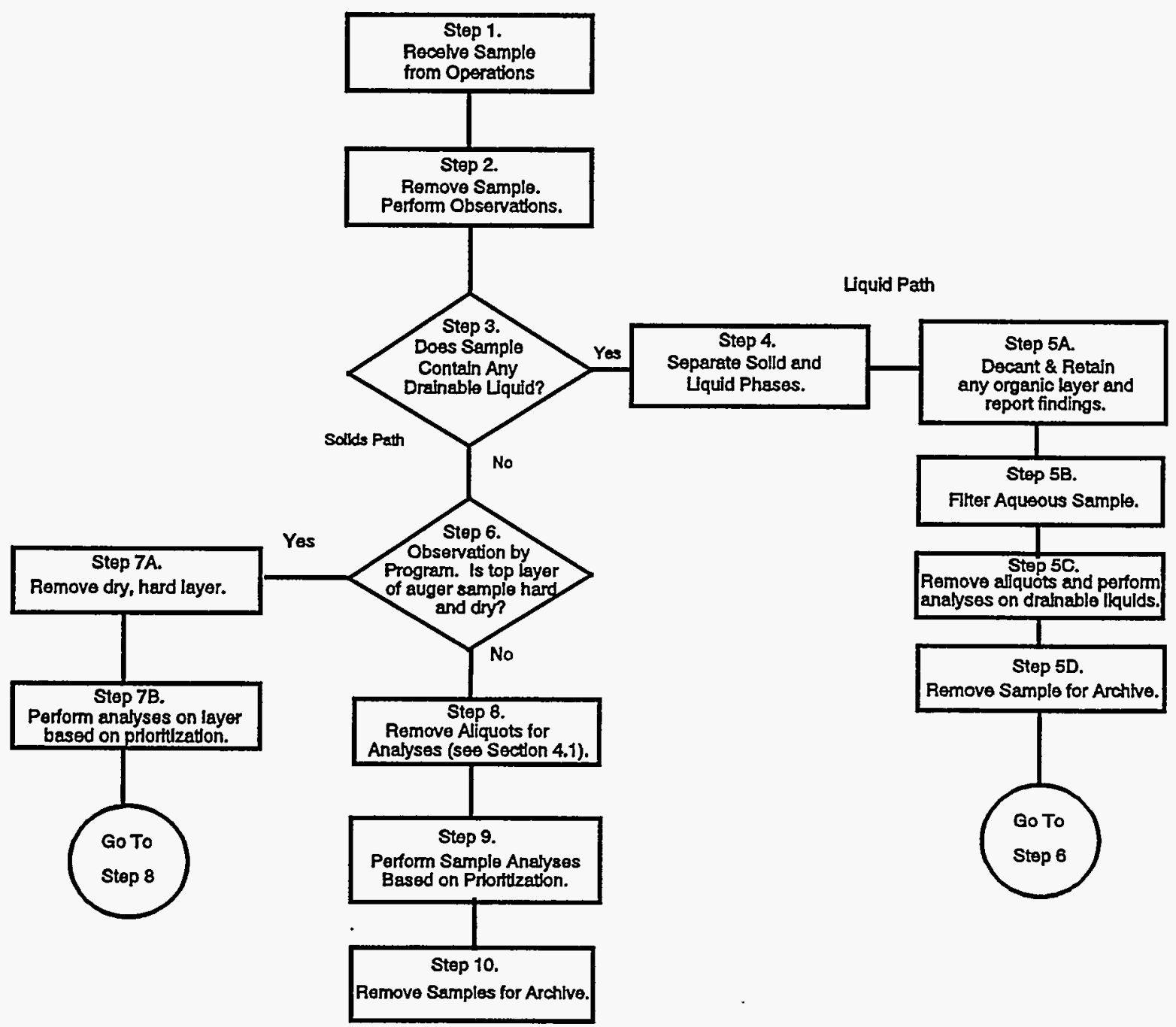

Figure A-2: Test Plan Flowchart for Tank AW-101. 
WHC-SD-WM-TP-229, REV. 0

\subsection{SPECIFIC ANALYTE, QUALITY CONTROL, AND DATA CRITERIA}

\subsection{SPECIFIC METHODS AND ANALYSES}

Table A-1 summarizes the analyses to be performed on the waste from tank AW-101. As we11, the laboratory procedure numbers which will be used in the analyses are included. These analyses are based on the Flammable Gas Safety Program's crust burn DQO (Johnson 1994).

For all of the analyses except DSC and TGA in Table A-1, one al iquot from each auger will be taken and duplicate runs will be performed for a total of six data points. For the DSC and TGA analyses, one aliquot from each end of each auger sample will be analyzed in duplicate, resulting in a total of 12 data points.

\subsection{QUALITY ASSURANCE/QUALITY CONTROL}

\subsubsection{Laboratory Operations}

The 222-S Laboratory has a quality assurance program plan (Meznarich 1994) and a quality assurance project plan (Taylor 1993) that shall provide the primary direction for the quality assurance/quality control involved in analyzing the AW-101 tank waste samples. In the event that analyses must be performed at the 325 Analytical Chemistry Laboratory (ACL), the analysis shal1 be guided by the $325 \mathrm{ACL}$ Quality Assurance Project Plan (Kuhl-Klinger 1994). Additionally, the Hanford Analytical Services Quality Assurance Plan, when implemented, shall be used as guidance.

Method specific quality control such as calibrations and blanks are also found in the analytical procedures. Sample quality control (duplicates, spikes, standards) are identified in Table A-1. If no criteria are provided in Table A-1, the performing laboratory shall perform to its quality assurance plan(s).

\subsubsection{Sample Collection}

Auger samples are to be taken and shipped to the performing laboratory by Sampling Operations in accordance with work package ES-94-906. That work package sha71 also initiate the chain-of-custody for the samples. Procedure T0-080-090 shall be used to transport and ship the sample casks. Samples shall be identified by a unique number before being shipped to the laboratory. The sampling team is responsible for documenting any problems and procedural changes affecting the validity of the sample in a field notebook. Sampling Operations shall enter this information in the comment section of the chain-of-custody form for addition to the data reports.

Sampling Operations should send samples to the laboratory within 1 day of removing the samples from tank AW-101, but must transport the samples within 3 calendar days of removal from the tank. Sampling Operations is responsible for verbally notifying the shift manager or project manager at the laboratory (373-2435 [222-S Laboratory]; 376-2639 [PNL 325 ACL]) at least 24 hours in advance of an expected shipment. If samples are going to be delivered after 3:00 pm, the laboratory shall be notified at least four hours in advance (72 hours for $325 \mathrm{ACL}$ ) of actual sample shipment so that proper shift operations can be planned. 


\subsubsection{Sample Custody}

The chain-of-custody form is initiated by the sampling team as described in the work package ES-94-906. Auger samples are shipped in a cask and sealed with a Waste Tank Sample Seal. All sample shipments are to be labeled with the following information:

WASTE TANK SAMPLE SEAL

Supervisor

Date of Sampling

Shipment No.
Sample No.

Time of Sampling

Serial No.

The sealed and labeled samples are shipped to the laboratory along with the chain-of-custody form, which includes tank and riser information. The receipt and control of samples in the Westinghouse Hanford 222-S Laboratory is described in L0-090-101. Receipt and control of samples in the $325 \mathrm{ACL}$ is described in procedure PNL-ALO-051. 
Table A-1. AW-101 Auger Sample Chemical

\begin{tabular}{|c|c|c|c|}
\hline Project Name & AW-101 Auger & \# AUGERS & AUGER \# \\
\hline Plan Number & WHC-SD-WM-TP-229, REV 0 & \multirow[t]{5}{*}{3} & \multirow[t]{5}{*}{1,2 , and 3} \\
\hline Tank & AW-101 & & \\
\hline Program Contact & G. D. Johnson & & \\
\hline TWRS Contact & $\begin{array}{l}\text { P. Sathyanarayana } \\
\text { R. D. Schreiber }\end{array}$ & & \\
\hline $\begin{array}{l}\text { Lab. Project } \\
\text { Coordinator }\end{array}$ & $\begin{array}{l}\text { K. E. Bell (WHC) } \\
\text { S. G. McKinley (PNL) }\end{array}$ & & \\
\hline
\end{tabular}

ANALYSES

\begin{tabular}{|c|c|c|c|c|c|c|c|c|}
\hline METHOD & ANALYTE & $\begin{array}{c}\text { WHC } \\
\text { PROCEDURE }\end{array}$ & $\begin{array}{c}\text { PNL } \\
\text { PROCEDURE }\end{array}$ & UNITS & $A C I D$ & FUS & $\mathrm{H}_{2} \mathrm{O}$ & OTHER \\
\hline Hot Persulfate & $\operatorname{TIC}\left(\mathrm{CO}_{3}{ }^{2-}\right)$ & LA-342-100 & PNL-ALO-381 & $\mu g / g$ & & & & direct \\
\hline Hot Persulfate & TOC & LA-342-100 & PNL-ALO-381 & $\mu \mathrm{g} / \mathrm{g}$ & & & & direct \\
\hline $\mathrm{DSC}^{2.8}$ & energy & LA-514-113 & PNL-ALO-508 & $\mathrm{J} / \mathrm{g}$ & & & & direct \\
\hline $\mathrm{TGA}^{2}$ & $\%$ water & LA-560-112 & PNL-ALO-508 & $\%$ & & & & direct \\
\hline $\mathrm{RSST}^{3}$ & energy & $\operatorname{see}^{5}$ & N/A & $\mathrm{J} / \mathrm{g}$ & & & & direct \\
\hline GEA $^{4}$ & Cs-137 & LA-548-121 & PNL-ALO-450 & $\mu \mathrm{Ci} / \mathrm{g}$ & & $x$ & $x$ & \\
\hline GEA $^{4}$ & $1-129$ & LA-378-103 & $\begin{array}{l}\text { PNL-ALO-450 } \\
\text { PNL-ALO-454 }\end{array}$ & $\mu \mathrm{Ci} / \mathrm{g}$ & & & & direct \\
\hline GEA $^{4}$ & $A m-241$ & LA-548-121 & $\begin{array}{l}\text { PNL-ALO-422 } \\
\text { PNL-ALO-489 }\end{array}$ & $\mu \mathrm{Ci} / \mathrm{g}$ & & $x$ & $x$ & \\
\hline Sep. \& $\beta$ count $^{4}$ & $\mathrm{Sr}-90$ & LA-220-101 & $\begin{array}{l}\text { PNL-ALO-431 } \\
\text { PNL-ALO-433 }\end{array}$ & $\mu \mathrm{Ci} / \mathrm{g}$ & & $x$ & $x$ & \\
\hline Sep. \& $a$ count $^{t}$ & Pu-239/240 & LA-503-156 & $\begin{array}{l}\text { PNL-ALO-422 } \\
\text { PNL-ALO-423 }\end{array}$ & $\mu \mathrm{Ci} / \mathrm{g}$ & & $x$ & $x$ & \\
\hline Sep. \& $\alpha$ count $^{4}$ & $\mathrm{~Np}-237$ & LA-933-141 & $\begin{array}{l}\text { PNL-ALO-422 } \\
\text { PNL-ALO-425 }\end{array}$ & $\mu \mathrm{Ci} / \mathrm{g}$ & & $x$ & $x$ & \\
\hline Liquid Scintillation & Tc-99 & LA-438-101 & PNL-ALO-432 & $\mu \mathrm{Ci} / \mathrm{g}$ & & $x$ & $x$ & \\
\hline
\end{tabular}

' ea - each, DUP - duplicate, spk/msd - spike or matrix spike duplicate,

PB - preparation blank per batch, AB - analytical batch, NA - not applicable.

2 One aliquot from each end of each auger, in duplicate, will be analyzed for DSC and TGA (see Section 4.1).

${ }^{3}$ RSST will be performed at the discretion of 222-S Laboratory personnel.

4 These analyses are performed only if the DSC measurement indicates an energy content greater than $140 \mathrm{cal} / \mathrm{g}$ (dry weight basis) or a dry crust is present in the tank. 


\section{Physical, and Radiological Analytical Requirements}

\section{COMMENTS}

Homogenization Test - Not Required

Field Blank - Not Required

Hot Cell Blank - Not Required

REPORTING FORMATS

\begin{tabular}{|l|l|}
\hline FORMAT I & Early Notify \\
\hline FORMAT II & Process Control \\
\hline FORMAT III & Safety Screen \\
\hline FORMAT IV & Waste Management \\
\hline FORMAT V & RCRA Compliance \\
\hline FORMAT VI & Special \\
\hline
\end{tabular}

\begin{tabular}{|c|c|c|c|c|c|c|c|c|}
\hline \multicolumn{4}{|c|}{ QUALITY CONTROL ${ }^{1}$} & \multicolumn{4}{|c|}{ CRITERIA } & \multirow{2}{*}{$\begin{array}{l}\text { REPORT } \\
\text { FORMAT }\end{array}$} \\
\hline DUP & SPK/MSD & BLANK & STD & PRECN & ACCRCY & $\begin{array}{l}\text { ACTION } \\
\text { LIMIT }\end{array}$ & $\begin{array}{l}\text { EXPECTED } \\
\text { RANGE }\end{array}$ & \\
\hline ea smpl & ea smpl & ea PB & ea $A B$ & $\leq 20 \%$ & $80-120 \%$ & none & $\begin{array}{l}15,000-20,000 \\
\mu \mathrm{g} / \mathrm{g}\end{array}$ & II \\
\hline ea smpl & ea smpl & ea PB & ea $A B$ & $\leq 20 \%$ & $80-120 \%$ & $30,000 \mu \mathrm{g} / \mathrm{g}$ & $\begin{array}{l}5000-20.000 \\
\mu \mathrm{g} / \mathrm{g}\end{array}$ & 1. II \\
\hline ea smpl & N/A & N/A & ea $A B$ & $\leq 20 \%$ & $80-120 \%$ & net $586 \mathrm{~J} / \mathrm{g}$ (dry) & -20 to $-70 \mathrm{cal} / \mathrm{g}$ & I, II \\
\hline ea smpl & N/A & N/A & ea $A B$ & $\leq 20 \%$ & $80-120 \%$ & none & $15-45 \%$ & II \\
\hline N/A & N/A & N/A & $N / A$ & $\leq 20 \%$ & $80-120 \%$ & net $586 \mathrm{~J} / \mathrm{g}(\mathrm{dry})$ & $>140 \mathrm{cal} / \mathrm{g}$ & 1. 11 \\
\hline ea smpl & N/A & ea PB & ea $A B$ & $\leq 20 \%$ & $80.120 \%$ & none & $300-500 \mu \mathrm{Ci} / \mathrm{g}$ & II \\
\hline ea smpi & ea smpl $\left.\right|^{6}$ & ea PB & ea $A B$ & $\leq 20 \%$ & $80-120 \%$ & none & $<1.0 \mu \mathrm{Ci} / \mathrm{g}$ & $\|$ \\
\hline ea smpl & ea smpl $\left.\right|^{6}$ & ea PB & ea $A B$ & $\leq 20 \%$ & $80-120 \%$ & none & $0.1-0.3 \mu \mathrm{Ci} / \mathrm{g}$ & II \\
\hline ea smpl & ea $\left.s m p\right|^{\sigma}$ & ea PB & ea $A B$ & $\leq 20 \%$ & $80-120 \%$ & none & $15-40 \mu \mathrm{Ci} / \mathrm{g}$ & II \\
\hline ea smpl & ea smpl $\left.\right|^{s}$ & ea PB & ea $A B$ & $\leq 20 \%$ & $80-120 \%$ & none & $\begin{array}{l}0.005-0.02 \\
\mu \mathrm{Ci} / \mathrm{g}\end{array}$ & $\|$ \\
\hline ea smpl & ea smpl ${ }^{7}$ & ea PB & ea $A B$ & $\leq 20 \%$ & $80-120 \%$ & none & $<0.1 \mu \mathrm{Ci} / \mathrm{g}$ & ॥ \\
\hline ea smpl & ea smpl $\left.\right|^{\sigma}$ & ea PB & ea $A B$ & $\leq 20 \%$ & $80-120 \%$ & none & $0.2-0.5 \mu \mathrm{Ci} / \mathrm{g}$ & $\|$ \\
\hline
\end{tabular}

${ }^{5}$ The RSST method, yet to be proceduralized, may be found in WHC-SD-WM-TP-104, Rev 0.

- Tracer or carrier is used in place of a spike and results corrected for recovery.

7 Post-digestion spike.

${ }^{\circ}$ DSC analysis shall be performed under air atmosphere. 
WHC-SD-HM-TP-229, REV. 0

\subsection{ORGANIZATION}

The organization and responsibility of key personnel involved in this tank AW-101 characterization project are listed in Table A-2.

Table A-2: Tank AW-101 Project Key Personnel List.

\begin{tabular}{|c|c|c|}
\hline Individual & Organization & Responsibility \\
\hline J. G. Kristofzski & $\begin{array}{l}\text { 222-S Analytical } \\
\text { Operations }\end{array}$ & $\begin{array}{c}\text { Program Support } \\
\text { Manager of Analytical } \\
\text { Operations }\end{array}$ \\
\hline S. G. Mckintey & $\begin{array}{c}325 \text { Analytical } \\
\text { Chemistry Laboratory }\end{array}$ & $\begin{array}{c}\text { Project Manager for } \\
\text { Tank Waste } \\
\text { Characterization }\end{array}$ \\
\hline P. Sathyanarayana & $\begin{array}{c}\text { TWRS Characterization } \\
\text { Support }\end{array}$ & $\begin{array}{c}\text { AW-101 Tank } \\
\text { Characterization Plan } \\
\text { Cognizant Engineer }\end{array}$ \\
\hline G. D. Johnson & $\begin{array}{c}\text { WHC Tank Waste Safety } \\
\text { Program }\end{array}$ & $\begin{array}{c}\text { Manager of } \mathrm{Flammable} \\
\text { Gas Safety Program }\end{array}$ \\
\hline J. L. Deichman & $\begin{array}{c}\text { Hanford Analytical } \\
\text { Services }\end{array}$ & $\begin{array}{c}\text { Manager of Hanford } \\
\text { Analytical Services } \\
\text { Program Management and } \\
\text { Integration }\end{array}$ \\
\hline $\begin{array}{c}\text { East Area } \\
\text { Operations Shift } \\
\text { Manager }\end{array}$ & Tank Farm Operations & $\begin{array}{c}\text { East Tank Farm Point } \\
\text { of Contact if Action } \\
\text { Limit is Exceeded } \\
(373-2689)\end{array}$ \\
\hline
\end{tabular}

\subsection{EXCEPTIONS AND PRIORITIES}

\subsection{EXCEPTIONS FOR TANK AH-101}

In the DQO, the accuracy and precision requirements are listed as "level of effort". This statement implies that very tight error tolerances are not necessary for the Flammable Gas Safety Program's decision rules. Therefore, the Flammable Gas Safety Program and the laboratories have decided that for the purposes of this sampling event and this Tank Characterization Plan, the precision and accuracy would be 7 isted as $\pm 20 \%$. It is reasonable to assume the laboratories can accomplish this level of precision, yet this level is stringent enough to satisfy the purposes of the Program. 


\subsection{PRIORITIES FOR TANK AH-101}

A prioritized list of analyses has been determined for tank AW-101. First, DSC and TGA analyses will be performed. If personnel at the performing laboratory, in agreement with the Flammable Gas Safety Program, feel there is sufficient need to warrant further energetics analyses, the RSST method will be used. If 325 ACL is the performing laboratory, sample material shall need to be sent to the 222-S Laboratory since the $325 \mathrm{ACL}$ does not have the capacity to perform the RSST method. If the net exothermic energy of tank $A W-101$ is greater than $140 \mathrm{cal} / \mathrm{g}$ on a dry weight basis, analyses for radionuclides (Cs-137, I-129, Am-241, Sr-90, Pu-239/240, $\mathrm{Np}-237$, and Tc-99) will be done. If the net exothermic energy in the tank is less than $140 \mathrm{cal} / \mathrm{g}$, but the in-tank camera shows a dry crust ring in the tank, the radiochemistry analyses will still be performed. G. D. Johnson of the Flammable Gas Safety Program shall inform the laboratory via written communication if a dry crust ring exists. Finally, if sufficient sample exists, the TOC analysis will be performed. This determination will be made during the hot cell operations, by a representative of the Program. The TOC analysis has the lowest priority because it is not necessary for resolution of the water addition or safety issue decision rule. Rather, a TOC analysis will, be performed to gain a general understanding of the tank contents relative to other Flammable Gas tanks.

\subsection{DELIVERABLES}

All analyses of tank AW-101 waste material will be reported as Formats I or II as shown in Table A-1. The Flammable Gas Safety Program may request progress reports from the laboratory regarding the analyses. However, due to the rapid turn around time required for the $A W-101$ analyses (the laboratories must report the results within 40 days of receipt of sample at the loading dock), no progress reports shall be required from the 1 aboratory. The data shall be reported in the units given by Table A-1. Detailed information regarding reporting formats is given in (Schreiber 1994a)

\subsection{FORMAT I REPORTING}

Table A-1 contains the notification Timits for each analyte. Any results that exceed the notification 1 imits defined in the DQO processes shal1 be reported immediately by calling the East Tank Farm Operations Shift Manager at 372-2689 and the Characterization Program office (Schreiber 1994b). This verbal notification must be followed within 1 working day by written communication to the Flammable Gas Safety Program, Analytical Services, Characterization Support, the Tank Characterization Resource Center, the Characterization Program office, and Waste Tanks Process Engineering, documenting the observations (Schreiber 1994c). Additional analyses for verification purposes may be contracted between the performing laboratory and the contacts above either by a revision to this document or by letter of instruction.

\subsection{FORMAT II REPORTING}

The data found from these analyses will determine whether or not water must be added when tank AW-10I is core sampled. Due to the immediate necessity of the DSC/TGA data, these results will be reported using a Laboratory Information Systems report or via electronic mail to the Flammable Gas Safety Program, as well as the Tank Characterization Resource Center and Tank Characterization Database representatives within 40 days of receipt of sample at the laboratory loading dock. 
WHC-SD-HH-TP-229, REV. 0

This analysis time Timit was agreed upon by the laboratory and the Flammable Gas Safety Program and allows ample time for the Program to determine if water must be added to tank AW-101 before core sampling is performed. The remaining analyses sha71 be reported within 136 days, as specified by the Tri-Party Agreement. In addition to the electronic report, a letter report to the Flammable Gas Safety Program, Analytical Services, the Characterization Program office, the Tank Characterization Resource Center, and Characterization Support shal1 document the results (Schreiber 1994c). The DSC and TGA scans have been requested due to the interpretive nature of the results.

\subsection{CHANGE CONTROL}

Under certain circumstances, it may become necessary for the performing laboratory to make decisions concerning a sample without review of the data by the customer or the Characterization Program. These changes shall be brought to the attention of the project coordinator and the Characterization Program as quickly as possible and documented accordingly. Changes may be documented through the use of internal characterization changes notices for minor, low-impact changes and documented in applicable laboratory notebooks. All significant changes shall be documented by an Engineering Change Notice to the Tank Characterization Plan. All changes shall also be clearly documented in the final data package.

Additional analysis of sample material from this characterization project at the request of the Characterization Program shall be performed according to a revision of this Tank Characterization Plan.

\section{REFERENCES}

Babad, H., 1992, An Overview of Progress Made Toward Resolving Priority One Safety Issues: Fiscal Year 1992, WHC-EP-0606, Westinghouse Hanford Company, Richland, Washington.

Conway, J. T., Letter to H. R. 0'Leary, DOE, "DNFSB Recommendation 93-5 to the Secretary of Energy," 9400070, dated Ju1y 19, 1993.

Hanion, B. M., 1993, Tank Farm Surveil7ance and Waste Status Summary Report for April 1994, WHC-EP-0182-73, Westinghouse Hanford Company, Richland, Washington.

Johnson, G. D., 1994, Data Requirements Developed Through the Data Quality Objectives Process for the Crust Burn Issue Associated with Flammable Gas Tanks, WHC-SD-WM-DQ0-003, Rev. 1, Westinghouse Hanford Company, Richland, Washington.

Johnson, G. D., Letter to R. E. Gerton, RL, "Notification of Intent to Conduct Activities at Double Shel1 Tanks," 9453468, dated May 20, 1994.

Kuhl-KTinger, K. J., 1994, Quality Assurance Plan for Activity Conducted by the Analytica7 Chemistry Laboratory, MCS-003, Rev. 1, Pacific Northwest Laboratory, Rich7and, Washington. 
Meznarich, H. K., 1994, Quality Assurance Program Plan for Laboratory Analysis and Process Testing, WHC-SD-CP-QAPP-003, Rev. 1, Westinghouse Hanford Company, Richland, Washington.

Redus, K. S., and H. Babad, 1994, Tank Safety Screening Data Quality Objective, WHC-SD-WM-SP-004, Westinghouse Hanford Company, Richland, Washington.

Schreiber, R. D., 1994a, Letter to C. S. Haller, "Interim Tank Characterization Plan Guidance", 7E720-94-112, dated Apri1 13, 1994.

Schreiber, R. D., 1994b, Letter to J. G. Kristofzski, "Format I Reporting Requirements", 7E720-94-128, dated August 15, 1994.

Schreiber, R. D., 1994c, Letter to J. G. Kristofzski, "Point of Contact/Distribution List", 7E720-94-141, dated October 11, 1994.

Taylor, L. H., 1993, Quality Assurance Project P7an for Chemical Analysis of Highly Radioactive Mixed. Waste Samples in Support of Environmental Activities on the Hanford Site, WHC-SD-CP-QAPP-002, Rev. 0, Westinghouse Hanford Company, Richland, Washington.

Whe 1an, T. E., et a7., 1994, TWRS Characterization Program Quality Assurance Program P7an, WHC-SD-WM-QAPP-025, Rev. 0, Westinghouse Hanford Company, Richland, Washington. 